\title{
Erratum to: Occupational Closure and Wage Inequality: How Occupational Closure Effects Vary Between Workers
}

\author{
Johannes Giesecke • Martin Groß $\cdot$ Stefan Stuth
}

Published online: 24 November 2021

(C) Der/die Autor(en) 2021

\section{Correction to:}

\section{Köln Z Soziol 2020}

https://doi.org/10.1007/s11577-020-00677-0

The article Occupational Closure and Wage Inequality: How Occupational Closure Effects Vary Between Workers, written by Johannes Giesecke, Martin Groß and Stefan Stuth, was originally published Online First without Open Access. After publication in volume 72, supplement 1, page 157-195 the author decided to opt for Open Choice and to make the article an Open Access publication. Therefore, the copyright of the article has been changed to The Author(s) 2020 and the article is forthwith distributed under the terms of the Creative Commons Attribution Attribution 4. 0 International License, which permits use, sharing, adaptation, distribution and reproduction in any medium or format, as long as you give appropriate credit to the original author(s) and the source, provide a link to the Creative Commons

The online version of the original article can be found under https://doi.org/10.1007/s11577-02000677-0

J. Giesecke $(\bowtie)$

Department of Social Sciences, Humboldt-Universität zu Berlin

Unter den Linden 6, 10099 Berlin, Germany

E-Mail: johannes.giesecke@hu-berlin.de

\section{Groß}

Department of Sociology, Tübingen University Wilhelmstraße 36, 72074 Tübingen, Germany

E-Mail: martin.gross@uni-tuebingen.de

S. Stuth

Institute of Sociology and Social Psychology, University of Cologne

Albertus Magnus Platz, 50923 Cologne, Germany

E-Mail: stuth@wiso.uni-koeln.de 
licence, and indicate if changes were made. The images or other third party material in this article are included in the article's Creative Commons licence, unless indicated otherwise in a credit line to the material. If material is not included in the article's Creative Commons licence and your intended use is not permitted by statutory regulation or exceeds the permitted use, you will need to obtain permission directly from the copyright holder. To view a copy of this licence, visit http:// creativecommons.org/licenses/by/4.0.

Open Access This article is licensed under a Creative Commons Attribution 4.0 International License, which permits use, sharing, adaptation, distribution and reproduction in any medium or format, as long as you give appropriate credit to the original author(s) and the source, provide a link to the Creative Commons licence, and indicate if changes were made. The images or other third party material in this article are included in the article's Creative Commons licence, unless indicated otherwise in a credit line to the material. If material is not included in the article's Creative Commons licence and your intended use is not permitted by statutory regulation or exceeds the permitted use, you will need to obtain permission directly from the copyright holder. To view a copy of this licence, visit http://creativecommons.org/licenses/by/4. $0 \%$ 